\title{
HERMENEUTIKA SEBAGAI PENDEKATAN DALAM KAJIAN ISLAM
}

\author{
Oleh: \\ Hariyanto \\ Fakultas Tarbiyah IAI Ibrahimy Situbondo \\ chori_p3m@yahoo.com
}

\begin{abstract}
:
The Qur'an as kalamullah descended to the Prophet Muhammad through the angel Gabriel as a miracle. The Qur'an is used as a guide for life for humans. To find the guidelines contained in it, the Qur'an is not only used as a readable scripture, but we must also understand the content of its meaning. The understanding of the content of Al-Qur'an content has been done by some great scholars. This understanding is done through several approaches, among others, with a hermeneutic approach.

The presence of hermeneutics can't be separated from the growth and advancement of thinking about language in the discourse of philosophy and other scholarship. Hermeneutics as a method of reading the text has been widely recognized in various fields of traditional Islamic scholarship, especially in the tradition of Fiqh and Tafsir al-Qur'an. Meanwhile, modern hermeneutics Islamic of ideology can basically be called a big leap in the formulating the methodology of Islamic ideoogy in general and the method of interpretation of the Qur'an in particular.
\end{abstract}

Key Words: Hermeneutika, Tafsir, Kajian Islam

\section{A. Pendahuluan}

Dalam kajian Islam (Islamic studies/dirasat islamiyyah), hermeneutika merupakan salah satu pendekatan yang digunakan untuk memahami ajaran Islam selain Filsafat, Linguistik, Sosiologi, Antropologi, Psikologi, Fenomenologi, dan Sejarah. Hermeneutika semakin menarik perhatian karena sempat menimbulkan pro dan kontra tentang penggunaan pendekatan ini terhadap teks al-Qur'an. Bagi yang keberatan terhadap pendekatan hermeneutika antara lain beralasan bahwa pendekatan ini berasal dari Barat yang sarat dengan kepentingan outsider (non-muslim) dalam pengkajian Islam. Sementara itu, bagi yang mendukung pendekatan ini antara lain berpandangan bahwa sebagai sebuah pendekatan, heremeneutika pada dasarnya netral sebagaimana antropologi, sejarah ataupun psikologi, tergantung pada kepentingan penggunanya. Bagi orang Islam tentu pendekatan hermeneutika 
digunakan untuk lebih memahami ajaran Islam yang dihadapkan pada berbagai tantangan jaman. Dalam praksisnya, secara substansial pendekatan ini sebenarnya telah lama digunakan oleh para pemikir muslim, hanya saja tidak secara eksplisit menggunakan terma hermeneutika.

Menurut Sudarto, hermeneutika pada dasarnya merupakan suatu metode atau cara untuk menafsirkan simbol yang berupa teks atau sesuatu yang diperlakukan sebagai teks untuk dicari arti dan maknanya, di mana metode hermeneutika ini mensyaratkan adanya kemampuan untuk menafsirkan masa lampau yang tidak dialami, kemudian dibawa ke masa sekarang. ${ }^{1}$ Pendekatan ini dapat digunakan untuk memahami dan menafsirkan berbagai macam permasalahan di banyak bidang seperti pendidikan, politik, hukum, dan teologi.

Salah satu bidang kajian agama yang paling menarik dikaji dengan menggunakan hermeneutika adalah kitab suci, sebab tidak semua kandungan kitab suci dapat dipahami oleh para pemeluknya sehingga membutuhkan penafsiran dari para mufasir.

Dalam konteks sejarah, agaknya tidak ada keseragaman dari para penafsir dalam memahami kitab suci sehingga muncul beragam kitab tafsir mulai dari era klasik sampai modern. Kewajiban para mufassir adalah berusaha menghadirkan penafsiran yang mudah diterima oleh para pembaca yang tidak dapat menafsirkan al-Qur'an secara langsung dikaitkan dengan konteks masyarakat yang dihadapi oleh komunitas pembaca. Terkait dengan hal tersebut, pada dasarnya seorang penafsir harus berhadapan dengan tiga budaya, yaitu budaya teks, budaya penafsir sendiri dan budaya pendengar.

Tulisan ini difokuskan pada beberapa persoalan, yaitu makna dan pentingnya pendekatan hermeneutika, cara kerja hermeneutika menurut para tokoh, dan contoh penerapan pendekatan hermeneutika dalam kajian Islam. Contoh yang dikemukakan di sini adalah hasil pemahaman Farid Esack, seorang pemikir muslim asal Afrika Selatan.

\section{B. Pembahasan}

\section{Perkembangan Pengertian Hermeneutik}

Kata hermeneutik berasal dari bahasa Yunani hermeneuein yang berarti "menafsirkan". Dalam mitologi Yunani, ada tokoh yang namanya dikaitkan dengan hermeneutik, yaitu Hermes, yang bertugas untuk

1 Sudarto, Metodologi Penelitian Filsafat, (Jakarta: PT. Raja Grafindo Persada, 1996), hlm. 85.

$$
400 \mid \text { JURNAL LISAN AL-HAL }
$$


menafsirkan kehendak dewa dengan bantuan kata-kata manusia agar manusia dapat memahami kehendak dewa, sebab bahasa dewa tidak dapat dipahami manusia. Dalam tradisi Islam, yang dimaksud Hermes tidak lain adalah Nabi Idris. ${ }^{2}$

Pengasosiasian Hermeneutika dengan Hermes secara sekilas menunjukkan adanya tiga unsur dalam aktifitas penafsiran, yaitu: [a] Tanda, pesan atau teks yang menjadi sumber atau bahan dalam penafsiran yang diasosiasikan dengan pesan yang dibawa oleh Hermes; [b] Perantara atau Penafsir (Hermes); dan [c] Penyampaian pesan oleh sang perantara agar bisa dipahami dan sampai kepada yang menerima. Ketiga unsur inilah yang menjadi unsur utama dalam hermeneutika, yaitu sifat-sifat teks, alat apa yang dipakai untuk memahami teks, dan bagaimana pemahaman dan penafsiran itu ditentukan oleh anggapan-anggapan dan kepercayaan-kepercayaan serta kondisi mereka yang menerima dan menafsirkan teks.

Pada awalnya, hermeneutika dikenal sebagai gerakan eksegesis (penafsiran teks-teks agama) di kalangan gereja yang berkembang menjadi "filsafat penafsiran". Selanjutnya, F.D.E. Schleiermacher yang dikenal sebagai "Bapak Hermeneutik Modern", membakukan hermeneutika sebagai metode umum interpretasi yang tidak hanya terbatas pada kitab suci dan sastra; Wilhelm Dilthey menerapkannya sebagaia metode sejarah, Hans Georg Gadamer mengembangkannya menjadi filsafat, dan Paul Ricoeur menjadikannya sebagai "metode penafsiran" baik dalam bidang filsafat, teologi, maupun ilmu-ilmu sosial dan humaniora.

Meskipun hermeneutika bisa dipakai sebagai alat untuk "menafsirkan" berbagai bidang kajian keilmuan, akan tetapi peran hermeneutika yang paling besar adalah dalam bidang ilmu sejarah dan kritik teks, khususnya kitab suci. ${ }^{3}$ Menurut Friedrich Shleiermacher, ada dua tugas hermeneutika yang pada hakikatnya identik satu sama lain, yaitu interpretasi gramatikal dan interpretasi psikologis. Aspek interpretasi gramatikal merupakan syarat berpikir setiap orang, sedangkan aspek interpretasi psikologis memungkinkan seseorang memahami pribadi penulis. Oleh karenanya, untuk memahami

2 Fakhruddin Faiz, "Teks, Konteks, Kontekstualisasi (Hermeneutika Moderen dalam Ilmu Tafsir al-Qur'an Kontemporer" dalam M. Amin Abdullah, dkk., Tafsir Baru Studi Islam dalam Era Multikultural, (Yogyakarta: IAIN Sunan Kalijaga dan Kurnia Kalam Semesta, 2002), hlm. 41. hlm. 161

3 Komaruddin Hidayat, Memahami BahasaAgama, (Jakarta: Paramadina, 1996),

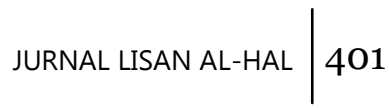


pernyataan-pernyataan dari pembicara, seseorang harus mampu memahami bahasanya sebaik ia memahami kejiwaannya. Semakin lengkap pemahaman seseorang atas sesuatu bahasa dan latar belakang psikologi pengarang, maka akan semakin lengkap pula interpretasinya terhadap karya pengarang tersebut. Kompetensi linguistik dan kemampuan memahami dari seseorang akan menentukan keberhasilannya dalam bidang seni interpretasi. Namun, pengetahuan yang lengkap tentang kedua hal tersebut kiranya tidak mungkin, sebab tidak ada hukum-hukum yang dapat mengatur bagaimana memenuhi kedua persyaratan tersebut. ${ }^{4}$

Schleiermacher menawarkan sebuah rumusan positif dalam bidang seni interpretasi, yaitu rekonstruksi historis, objektif dan subjektif terhadap pernyataan. Melalui rekonstruksi objektif-historis, ia bermaksud membahas sebuah pernyataan dalam hubungannya dengan bahasa sebagai keseluruhan. Melalui rekonstruksi subjektif-historis, ia bermaksud membahas awal mula sebuah pernyataan masuk ke dalam pikiran seseorang. Schleiermacher sendiri menyatakan bahwa tugas hermeneutika adalah memahami teks lebih baik daripada pengarangnya sendiri dan memahami pengarang teks lebih baik daripada memahami diri sendiri.

Schleiermacher juga menegaskan adanya masalah hermeneutical circle atau lingkaran hermeneutika, yaitu bahwa untuk memahami sebagian dari teks, pembaca memerlukan pemahaman atas konteks keseluruhan teks, dan untuk memahami keseluruhan teks, pembaca memerlukan pemahaman akan sumber-sumber lain untuk membantu pemahamannya, termasuk pemahaman akan kehidupan dan minat penulis. Hal ini juga memerlukan pemahaman akan konteks budaya di mana karya tulis tersebut muncul.

Secara umum, hermeneutika dapat dibagi menjadi dua, pertama, hermeneutical theory yang berisi aturan metodologis untuk sampai kepada pemahaman yang diinginkan pengarang (author), dan lebih memusatkan perhatian kepada bagaimana memperoleh makna yang tepat dari teks atau sesuatu yang dipandang sebagai teks. Kedua, hermeneutical philosophy yang lebih mencermati dimensi filosofis-fenomenologis pemahaman di mana penafsiran dilakukan dengan melangkah jauh ke dalam aspek historisitas, tidak hanya dalam dunia teks, tetapi juga dunia pengarang dan dunia pembacanya. ${ }^{5}$

4 E. Sumaryono, Hermeneutik: Sebuah Metode Filsafat, (Yogyakarta: Kanisius, 1999), hlm. 41.

5 Hans George Gadamer, Truth and Method, (New York: the Seabury Press, 1975),

402 JURNAL LISAN AL-HAL 


\section{Hermeneutika dan Ilmu Tafsir Al-Qur'an}

Istilah hermeneutika dalam sejarah keilmuan Islam, khususnya tafsir Al-Qur'an klasik, memang tidak ditemukan. Akan tetapi, praktek hermeneutika sebenarnya telah dilakukan oleh umat Islam sejak lama, khususnya ketika menghadapi Al-Qur'an. Sebagai bukti, menurut Farid Esack, adalah: ${ }^{6}$

a. Problematika hermeneutika senantiasa dialami dan dikaji, meski tidak ditampilkan secara definitif. Hal ini terbukti dari kajian-kajian mengenai asbabun-nuzul dan nasikh-mansukh.

b. Perbedaan antara komentar-komentar yang aktual terhadap Al-Qur'an (tafsir) dengan aturan, teori atau metode penafsiran telah ada sejak mulai munculnya literatur-literatur tafsir yang disusun dalam bentuk ilmu tafsir.

c. Tafsir tradisional selalu dimasukkan dalam banyak kategori, seperti tafsir syi'ah, tafsir mu'tazilah, tafsir hukum, tafsir filsafat, tafsir tasawuf, dan tafsir sains. Hal ini menunjukkan adanya kelompokkelompok tertentu, ideologi-ideologi tertentu, periode-periode tertentu, maupun horison-horison sosial tertentu dari tafsir.

Dalam kurun modern, operasionalisasi hermeneutika dalam penafsiran Al-Qur'an dirintis oleh para pembaharu muslim seperti Ahmad Khan di India yang berusaha melakukan demitologisasi konsep-konsep dalam Al-Qur'an yang dianggap bersifat mitologis, seperti mengenai mukjizat dan hal-hal gaib, Muhammad Abduh di Mesir yang secara operasional melakukan operasi hermeneutika dengan bertumpu pada analisis sosial-kemasyarakatn, dan Fazlur Rahman asal Pakistan yang menawarkan metodologi "Double Movement". Menurutnya, penafsiran dua arah adalah merumuskan visi dan misi Al-Qur'an yang utuh dan kemudian menerapkan prinsip umum tersebut dalam situasi kekinian. ${ }^{7}$ Arah pertama menekankan pada pencarian ide moral dalam konteks ketika al-Qur'an diturunkan, sementara arah kedua berupaya menerapkan ide moral tersebut untuk mengatasi persoalan kekinian.

hlm. xvi.

${ }^{6}$ Farid Esack, Qur'an: Liberation \& Pluralism (Oxford: One World, 1997), hlm. 161.

7 Taufik Adnan Amal, Metode dan Alternatif Neomodernisme Fazlur Rahman, (Bandung: Mizan, 1990), hlm. 32. 
Skema Hermeneutika Double Movement Fazlur Rahman

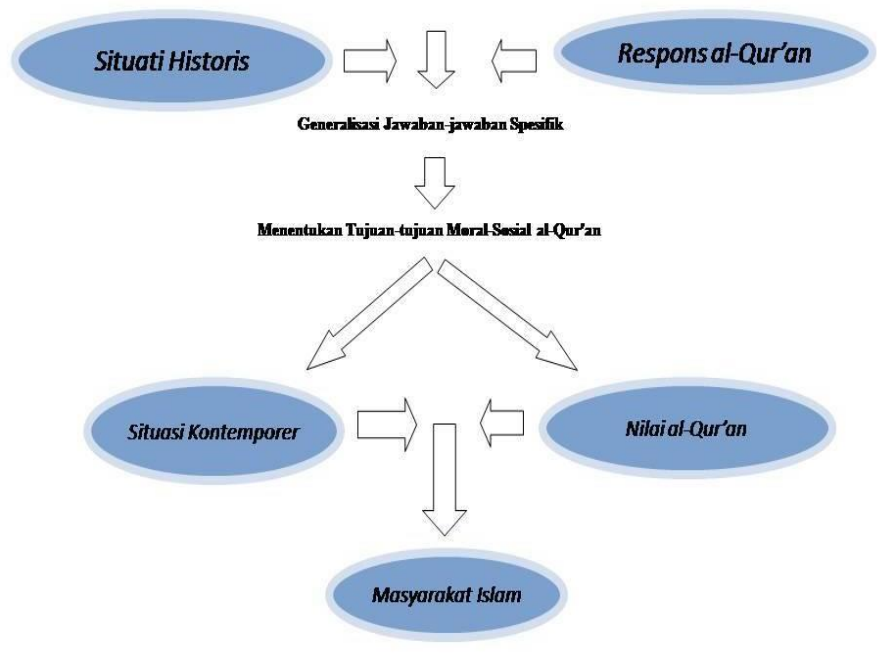

\section{Problem Hermeneutika dalam Tafsir Al-Qur'an}

Secara epistimologi, terbukti bahwa kelahiran tafsir hermeneutika tidak bisa lepas dari sejarah Yahudi dan Kristen, ketika mereka dihadapkan pada pemalsuan kitab suci dan monopoli penafsiran kitab suci gereja. Dengan teori linguistik, mereka susun tahap wahyu untuk menjustifikasi keabsahan tafsiran mereka yang sama-sama bersumber dari wahyu, meski bukan wahyu verbal. Meski begitu, hermeneutika tetap tidak bisa menyelamatkan kitab suci mereka dari praktek pemalsuan, termasuk tidak lepas dari problem besar, hermeneutic circle. Realitas ini tidak dihadapi umat Islam, baik menyangkut pemalsuan kitab suci maupun monopoli penafsiran. Dalam Islam ada ilmu riwayat yang tidak pernah disentuh oleh hermeneutika. Dengan ilmu ini, autentisitas alQur'an dan Hadis bisa dibuktikan, disimpulkan, bahwa pembukuan alQur'an itu perintah Allah, bukan karena faktor sosial atau politik. ${ }^{8}$

Dari sini bisa disimpulkan bahwa sejarah yang melatarbelakangi lahirnya hermeneutika adalah sejarah pemalsuan kitab suci dan monopoli penafsiran pihak gereja. Anggapan inilah yang telah melahirkan hermeneutika sebagai kaidah interpretasi-epistemologis. Anggapan ini tidak terpikir oleh umat Islam. Baru setelah abad ke-20, anggapan ini dikembangkan oleh kaum terpelajar muslim yang belajar di Barat,

\footnotetext{
${ }^{8}$ Hafidz Abdurrahman, Kebobrokan Tafsir Hermeneutika, hlm. 4.
} 
sehingga seakan-akan umat Islam menghadapi persoalan dengan kitab suci mereka, seperti yang dihadapi umat lain.

Dengan dalih obyektivitas, hermeneutika sebagai interpretasiepistemologis telah menolak semua anggapan untuk membangun kesimpulannya. Tetapi kenyataannya, anggapan itu tidak pernah bisa dielakkan. Inilah yang kemudian disebut dengan problem besar, hermeneutic circle (lingkaran setan tafsiran). Ini sekaligus menunjukkan kesalahan teori ini sebagai metode berpikir. Dengan dalih obyektifitas, semua anggapan dibuang, padahal obyek kajian yang dihadapi bukanlah realitas empiris yang bisa diuji dengan kaidah eksperimental layaknya obyek kajian ilmiah. Kesalahan inilah yang menyebabkan kesalahankesalahan berikutnya, termasuk ketika teori ini digunakan untuk menafsirkan al-Qur'an.

Meskipun dalam beberapa kasus metode ini sempat diragukan, akan tetap tidak bisa dipungkiri bahwa metode ini juga bisa diadopsi oleh umat Islam sebagai alternatif untuk menafsirkan al-Qur'an dan Hadis dengan catatan tidak meninggalkan keautentisitasannya.

\section{Mengolah Teks, Melacak Makna}

Hermeneutika pada mulanya berhubungan dengan bahasa; sementara kehidupan manusia tidak bisa lepas dari bahasa. Manusia menulis, berpikir, memahami, berbicara dan lain sebagainya melalui bahasa. Langkah langkah awal dalam penafsiran Al-Qur'an adalah memahami teksnya, yakni melihatnya dari aspek kebahasaannya, yaitu bahasa Arab. Hanya dengan terlebih dulu memahami teks atau aspek kebahasaan inilah nantinya seorang penafsir bisa memahami baik makna, hikmah maupun hukum dari Al-Qur'an secara tepat.

Ketika teks Al-Qur'an dihadapkan pada "alat olah" hermeneutika, maka teks Al-Qur'an akan diperlakukan sama seperti teks-teks lainnya, di mana untuk memahaminya seseorang dituntut untuk mampu menangkap makna yang ada dalam teks tersebut, dengan mempertimbangkan bagaimana teks tersebut dipahami oleh masyarakat di mana ia turun dan bagaimana teks tersebut harus dipahami dalam konteks yang berbeda dalam upaya kontekstualisasi.

\section{Memahami Konteks dan Proses Kontekstualisasi}

Langkah kedua dalam penafsiran perspektif hermeneutika adalah dengan melihat konteks dari teks sebelum merumuskan dan menentukan makna teks yang sebenarnya. Penggalian terhadap makna teks yang hanya berhenti pada isi teks tanpa mau melihat konteks, yaitu latar belakang dan

$$
\text { JURNAL LISAN AL-HAL } \mid 405
$$


setting historis yang ada di balik teks pada akhirnya hanya akan membawa pemahaman yang parsial dan penafsiran yang tidak tepat sasaran.

Pemahaman terhadap konteks sejarah yang menjadi latar belakang munculnya ayat-ayat Al-Qur'an bisa dikatakan merupakan satu komponen vital untuk mengantarkan kepada pemahaman yang tepat terhadap AlQur'an. Apa yang menyebabkan Al-Qur'an turun dan bagaimana generasi yang mengalami langsung Al-Qur'an tersebut menyikapinya adalah poin utama yang tidak boleh ditinggalkan. Urgensi terhadap konteks kesejarahan ini terletak pada realita bahwasannya sebagian besar muatan Al-Qur'an berkaitan dengan situasi keagamaan, keyakinan, pandangan dunia dan adat-istiadat masyarakat tempat ia turun, yaitu Arab. Bukti jelas mengenai asumsi ini adalah diturunkannya Al-Qur'an secara berangsurangsur selama 23 tahun masa kenabian Muhammad dan fenomena nasikh dan mansukh dalam ayat-ayat Al-Qur'an. ${ }^{9}$

Karena begitu pentingnya konteks inilah, maka banyak para pemikir modern yang berusaha menggarapnya dengan serius, seperti yang dilakukan oleh Fazlur Rahman yang memberikan tiga patokan awal dalam penafsiran. Ketiga rumusan tersebut adalah pentingnya pendekatan sejarah diturunkannya al-Qur'an dalam konteks sosial, tujuan diturunkannya ayat al-Qur'an, dan sasaran diturunkannya ayat al-Qur'an secara sosiologis: ${ }^{10}$

Pemahaman terhadap konteks kesejarahan ini membawa beberapa manfaat dalam penafsiran, seperti:

a. Memudahkan dalam mengidentifikasi gejala-gejala moral dan sosial masyarakat Arab ketika itu, sikap Al-Qur'an terhadapnya, dan cara AlQur'an memodifikasi atau mentransformasi gejala tersebut sehingga sejalan dengan pandangan Al-Qur'an.

b. Menjadi pedoman bagi umat Islam untuk mengidentifikasi dan menangani problem-problem yang mereka hadapi.

c. Terhindar dari praktek-praktek pemaksaan pra-konsepsi dalam penafsiran.

Kesadaran akan pentingnya konteks sejarah dalam memahami ayat-ayat Al-Qur'an dalam ilmu tafsir Al-Qur'an sangat dikenal dalam disiplin kajian Asbab an-Nuzul, di mana isi dari kajian ini adalah menelaah latar belakang diturunkannya ayat-ayat Al-Qur'an kepada Nabi. Di samping bertujuan untuk mengetahui latar belakang turunnya ayat $\mathrm{Al}$ -

\footnotetext{
${ }^{9}$ Fakhruddin Faiz, "Teks, Konteks, dan Kontekstualisasi”, hlm. 55.

10 Fazlur Rahman, Cita-cita Islam, terj. Suyanto (Yogyakarta: Pustaka Pelajar, 2000), hlm. 52-54.
}

406 JURNAL LISAN AL-HAL 
Qur'an, disiplin kajian ini pada akhirnya juga sangat membantu dalam melacak makna dan spirit (semangat) dari suatu ayat, di mana hal ini tentunya sangat berguna dalam upaya kontekstualisasi ayat untuk waktu dan tempat yang berbeda.

Dengan melihat setting sosial-historis diharapkan dapat dilacak bagaimana masyarakat yang menjadi penerima teks tersebut memahami teks yang dimaksud. Asumsi dasar dari pandangan ini adalah bahwasannya setting sosio-historis yang berbeda akan memunculkan pemahaman yang berbeda, sehingga seorang yang akan berbicara terhadap satu masyarakat harus bisa menyesuaikan dengan kondisi masyarakat tersebut agar apa yang disampaikannya bisa dipahami secara cepat.

Pemahaman terhadap Al-Qur'an dalam konteksnya sebagaimana di atas, menjadi kajian yang bersifat akademis-murni jika tidak diproyeksikan untuk memenuhi kebutuhan-kebutuhan kontemporer. Di sinilah perlunya kontekstualisasi, dalam arti upaya untuk menerapkan makna teks yang dipahami dari suatu wacana dalam konteks tertentu di masa yang telah lalu dengan konteks yang berbeda di masa kini.

Ada dua asumsi dasar yang melatar belakangi perlunya kontekstualisasi ini, yaitu:

a. Al-Qur'an adalah dokumen untuk manusia, harus selalu dapat memberikan bimbingan kepada manusia dalam hidup dan kehidupan mereka. Karena Al-Qur'an merupakan sumber dan tata nilai mereka.

b. Al-Qur'an sebagai petunjuk Allah yang jelas berkaitan dengan manusia dengan pesan-pesannya yang bersifat universal dan telah disepakati oleh seluruh umat Islam. Persoalan yang timbul adalah bagaimana agar pesan-pesan Al-Qur'an yang universal itu bisa ditangkap dan dimanfaatkan oleh setiap orang pada setiap masa.

Meskipun tidak mudah untuk melaksanakan kontekstualisasi AlQur'an tersebut, dalam kajian kepustakaan muslim banyak muncul kitab tafsir Al-Qur'an dengan tokoh dan ciri khasnya yang berusaha untuk memahami Al-Qur'an secara kontekstual.

Kontekstualisasi berarti melihat realitas historis yang sedang terjadi pada saat ini, kemudian mencari pedoman dan petunjuk Al-Qur'an mengenai apa yang harus diharapkan. Di sinilah sebenarnya inti dari operasi hermeneutika, yang berarti menafsirkan secara reproduktif, dalam arti tidak sekedar mencari pemahaman apa yang dimaksud oleh teks semata, tetapi juga mencari apakah teks bermakna untuk masa kini. 


\section{Penerapan Hermeneutik: Kasus Farid Esack}

Sebagai pemikir muslim yang berlatar belakang aktivis, Farid Esack mempunyai keuniakan tersendiri ketika menafsirkan beberapa terma dalam al-Qur'an. Pengalaman hidupnya di tengah iklim politik apartheid dan pergaulannya dalam konteks masyarakat majemuk menjadikannya seorang pemikir yang kritis dan dinamis mencari alternatif pemecahan dari berbagai persoalan yang dihadapi masyarakatnya. Bahkan, hal ini berpengaruh terhadap model penafsirannya terhadap al-Qur'an yang juga cukup kritis dan dinamis. Baginya, al-Qur'an harus terus dikontekstualisasikan nilai dasarnya di mana pun orang Islam berada.

Yang dikritik Esack dari model penafsiran Rahman adalah bahwa Rahman dianggap kurang mengapresiasi terhadap kompleksitas tugas heremeneutika dan pluralitas intelektual yang intrinsik. Rahman dianggap lebih menekankan aspek kognisi dan relatif mengabaikan hubungan antara kognisi dan wilayah praksis. Misalnya, ketika berbicara tentang ide keadilan, Rahman dianggap "melupakan" aspek struktural sebagai penyebab utama ketidakadilan dalam masyarakat. ${ }^{11}$

Dalam konteks ini, ada tiga terma yang akan dikemukakan sebagai wujud penafsiran Esack dengan pendekatan hermeneutika, yaitu taqwa, tauhid, dan mustad'afin.

a. Taqwa

Menurut Esack, taqwa merupakan terma paling komprehensif, inklusif dan aplikatif yang meliputi tanggung jawab di hadapan Tuhan dan manusia. Hal ini dapat dilihat dalam QS. 92: 4-10 dan QS. 49: 13. Dengan taqwa, individu dan komunitas memikul tugas kenabian dalam proses transformasi dan pembebasan (QS. 3: 102-105; 8: 29). Menurutnya, menerima taqwa sebagai kunci hermeneutika memiliki implikasi penting bagi penafsir dan tindakan menafsir, yaitu: a) penafsiran harus terbebas dari prasangka (zann) dan nafsu (hawa); b) taqwa memfasilitasi keseimbangan estetik dan spiritual dalam kehidupan penafsir; c) taqwa mendorong komitmen penafsir pada proses dialektika personal dan transformasi sosio-politik. Keterlibatan Al-Qur'an dalam proses perjuangan revolusi juga berarti keterlibatan diri penafsir dalam revolusi tersebut. ${ }^{12}$

11 Zakiyuddin Baidhawy, “Hermeneutika Pembebasan al-Qur'an: Perspektif Farid Esack" dalam PROFETIKA Jurnal Studi Islam, Vol. 3, No. 2, Juli 2001, hlm. 295.

${ }^{12}$ Farid Esack, Qur'an, hlm. 88-89.

408 JURNAL LISAN AL-HAL 


\section{b. Tauhid}

Tauhid merupakan kesatuan Tuhan untuk kesatuan manusia. Tauhid adalah fondasi, pusat dan tujuan dari keseluruhan tradisi Islam. Ia adalah jantung pandangan dunia sosio-politik, dan tumbuh secara meyakinkan dalam revolusi Iran 1979. Ali Shariati adalah cendekiawan yang menyatakan tauhid sebagai pandangan dunia yang bertujuan merealisasikan kesatuan Tuhan dalam relasi manusia dan sistem sosioekonomi. Tauhid oleh para penafsir di Afrika Selatan digunakan untuk melawan pemisahan antara agama dan politik, dan apartheid sebagai ideologi. Tauhid adalah sumber ideologi dan kerangka rujukan suci. Bagi Esack, tauhid mempunyai dua implikasi dalam konteks Afrika Selatan, yaitu: a) pada level eksistensial, yang berarti penolakan atas dualisme konsepsi tentang eksistensi manusia di mana perbedaan dibuat antara sekuler dan spiritual, dan b) pada level sosio-politik, bahwa ia menentang masyarakat yang menjadikan ras sebagai objek alternatif bagi pemujaan dan membedakan penduduk atas dasar etnisitas. Pembedaan semacam ini adalah shirk, antitesis dari tauhid. Dengan demikian, bagi Esack, politik apartheid adalah shirk.13

c. Al-Mustad'afun, Fuqara', dan Masakin

Ketiga terma tersebut bermakna kelas marginal, tertindas. Mereka merupakan lawan dari mutrafun, mala', dan mustakbirun. Nabi Muhammad berasal dari keluarga petani dan kelas pekerja; demikian juga para Nabi Ibrahim berasal dari keluarga petani dan penggembala domba. Mereka mempunyai tujuan menciptakan tatanan sosial yang egaliter; mereka menghapuskan ketidakadilan sosio-ekonomi seperti rente, bunga, dan semua praktek ekonomi spekulatif dan eksploitatif. Al-Qur'an melarang akumulasi kekayaan, memerintahkan pembebasan wanita dan budak. Banyak ayat yang menghubungkan iman dan agama dengan keadilan sosio-ekonomi. Bagi Esack, seorang penafsir perlu menempatkan dirinya di tengah-tengah kaum marginal dan dalam perjuangan mereka sekaligus menafsirkan teks dari bagian bawah sejarah, didasarkan atas paham pilihan Tuhan dan kenabian atas orang-orang tertindas. ${ }^{14}$

\section{Simpulan}

Sebagai sebuah pendekatan yang menggarap wilayah penafsiran baik kitab suci ataupun teks secara umum, hermeneutika tidak hanya memandang teks dan makna literalnya, namun juga menggali makna

13 Ibid., hlm. 92.

14 Ibid., hlm. 98-103. 
dengan mempertimbangkan horison-horison yang melingkupi teks tersebut. Horison yang dimaksud adalah horison teks, horison pengarang dan horison pembaca atau penerima.

Dengan memperhatikan ketiga horison tersebut, diharapkan suatu upaya pemahaman ataupun penafsiran menjadi kegiatan rekonstruksi dan reproduksi makna teks, di mana di samping melacak bagaimana satu teks dimunculkan oleh pengarangnya dan muatan apa yang masuk dan ingin dimasukkan oleh pengarang ke dalam teks yang dibuatnya; juga berusaha melahirkan kembali makna tersebut sesuai denga situasi dan kondisi saat teks tersebut dibaca atau dipahami. Dengan demikian, variabel utama dalam aktifitas penafsiran dengan pendekatan hermeneutika adalah teks, konteks, dan kontekstualisasi.

\section{DAFTAR PUSTAKA}

Abdurrahman, Hafidz, Kebobrokan Tafsir Hermeneutika, http://swaramuslim.net/more.php?id=A2215 $010 \mathrm{M}$

E. Sumaryono, Hermeneutik: Sebuah Metode Filsafat, Yogyakarta: Kanisius, 1999.

Fakhruddin Faiz, "Teks, Konteks, Kontekstualisasi (Hermeneutika Moderen dalam Ilmu Tafsir al-Qur'an Kontemporer" dalam M. Amin Abdullah, dkk., Tafsir Baru Studi Islam dalam Era Multikultural, Yogyakarta: IAIN Sunan Kalijaga dan Kurnia Kalam Semesta, 2002.

Farid Esack, Qur'an: Liberation \& Pluralism, Oxford: One World, 1997.

Fazlur Rahman, Cita-cita Islam, terj. Suyanto, Yogyakarta: Pustaka Pelajar, 2000.

Fazlur Rahman, Islam and Modernity, Chicago: Chicago University Press, 1984.

Hans George Gadamer, Truth and Method, New York: the Seabury Press, 1975.

Komaruddin Hidayat, Memahami BahasaAgama, Jakarta: Paramadina, 1996.

Sudarto, Metodologi Penelitian Filsafat, Jakarta: PT. Raja Grafindo Persada, 1996

Taufik Adnan Amal, Metode dan Alternatif Neomodernisme Fazlur Rahman, Bandung: Mizan, 1990.

Zakiyuddin Baidhawy, "hermeneutika Pembebasan al-Qur'an: Perspektif Farid Esack" dalam PROFETIKA Jurnal Studi Islam, Vol. 3, No. 2, Juli 2001.

$410 \mid$ JURNAL LISAN AL-HAL 